\title{
Natural Wood Resistance of Mimosa caesalpiniifolia in Field Testing
}

\author{
João Batista Silva Araujo ${ }^{1}$, Juarez Benigno Paes ${ }^{2}$ \\ ${ }^{1}$ Centro Regional de Desenvolvimento Rural, Centro-Serrano, Instituto Capixaba de Pesquisa Assistência Técnica e \\ Extensão Rural - INCAPER, Domingos Martins/ES, Brazil \\ ${ }^{2}$ Departamento de Ciências Florestais e da Madeira, Universidade Federal do Espírito Santo - UFES, \\ Jerônimo Monteiro/ES, Brazil
}

\begin{abstract}
The natural wood resistance of sabiá (Mimosa caesalpiniifolia) was evaluated under field conditions for use in organic agriculture. A total of 97 one-meter length logs with bark and diameter classes (5.0-7.9 and 8.0-11 cm) were fixed $(0.4 \mathrm{~m})$ in the soil at a distance of $0.5 \mathrm{~m}$ from the edges of a forest fragment in Viana, Espírito Santo, Brazil and evaluated after 5 years and 5 months for their resistance to breaking through the application of manual force. The presence of xylophagous termites and fungi was verified. The percentages of unbroken pieces of wood were $81.82 \%$ and $79.24 \%$ respectively for the larger and smaller diameter classes. For the smaller diameter class, $52.83 \%$ showed moderate to superficial attacks, and the largest diameter class had $61.36 \%$. In this case, $41 \%$ of the pieces presented superficial attacks (by termites and fungi) or were not attacked, confirming good performance of the tested wood.
\end{abstract}

Keywords: natural durability, fence posts, xylophagous organisms. 


\section{INTRODUCTION}

Sabiá (Mimosa caesalpiniifolia Benth.), also known as sansão-do-campo, is a small tree occurring naturally in the states of Rio Grande do Norte, Piauí and Ceará, Brazil. The species has multiple uses such as for honey, foraging, firewood and charcoal production and as fence posts (Carvalho, 2007).

Due to its rapid growth, thorns and landscaping attributes, Mimosa caesalpiniifolia are planted to form live fences on properties in the Southeast, South and Midwest Regions of Brazil. The wood of this species has an average basic density of $0.80 \mathrm{~g} \mathrm{~cm}^{-3}$ (Gonçalves et al., 1999).

Mimosa caesalpiniifolia fence posts are traditionally used in the Northeast Region to construct fences due to its natural durability (Carvalho et al., 2004). For this purpose, production varies from 4,000 and 9,000 rounded pieces per hectare, and logging is carried out at intervals of 3 to 4 years after planting (Ribaski et al., 2003). Its use for fence posts makes it a potential resource for farmers in other Brazilian regions, especially in organic systems where the use of treated wood is not recommended.

An experiment carried out in field conditions using round posts of sombreiro (Clitoria fairchildiana), eucalypts (Corymbia citriodora), gmelina (Gmelina arborea), chuva-de-ouro (Lophantera lactescens), sabiá (Mimosa caesalpiniifolia) and rain tree (Samanea saman) with bark, found that of the 169 coleopteran larvae of the Scolytinae subfamily collected, only two were found in Mimosa caesalpiniifolia (Lunz \& Carvalho, 2002) after 200 days.
Under laboratory conditions, Melo \& Paes (2006) found that wood from sabiá (Mimosa caesalpiniifolia) and jurema-preta (Mimosa tenuiflora) were more resistant than those from louro-pardo (Cordia trichotoma) and marmeleiro-preto (Croton sonderianus) to Postia placenta and Polyporus fumosus xylophagous fungal attack, classifying sabiá wood as very resistant to the fungi tested. Natural wood resistance of phenotypes with and without thorns to subterranean termite (Nasutitermes corniger) attack was verified by Alencar et al. (2011), who observed low mass losses $(<10 \%)$ in samples obtained from the tested phenotypes, classifying them as resistant to the evaluated termites.

Due to the resistance of sabia wood to the biological deterioration in field conditions in Northeastern Brazil, this study aimed to evaluate the natural resistance of this wood for its use in fences and as supports for climbing plants in organic agriculture, under edaphoclimatic conditions favorable to xylophagous agents development.

\section{MATERIAL AND METHODS}

In order to evaluate the natural resistance of sabiá wood (Mimosa caesalpiniifolia Benth.) in contact with the soil, 97 one-meter length logs with bark and diameters ranging from 5 to $11 \mathrm{~cm}$ were used; these logs were collected from trees grown as hedges at approximately 10 years of age.

$0.4 \mathrm{~m}$ of the log was buried in the ground, at a distance of $0.5 \mathrm{~m}$ from each other and randomly distributed along a continuous line at the edge of a forest fragment (Figure 1), at the Rural Leadership Improvement Center (CALIR) belonging to the Capixaba Institute

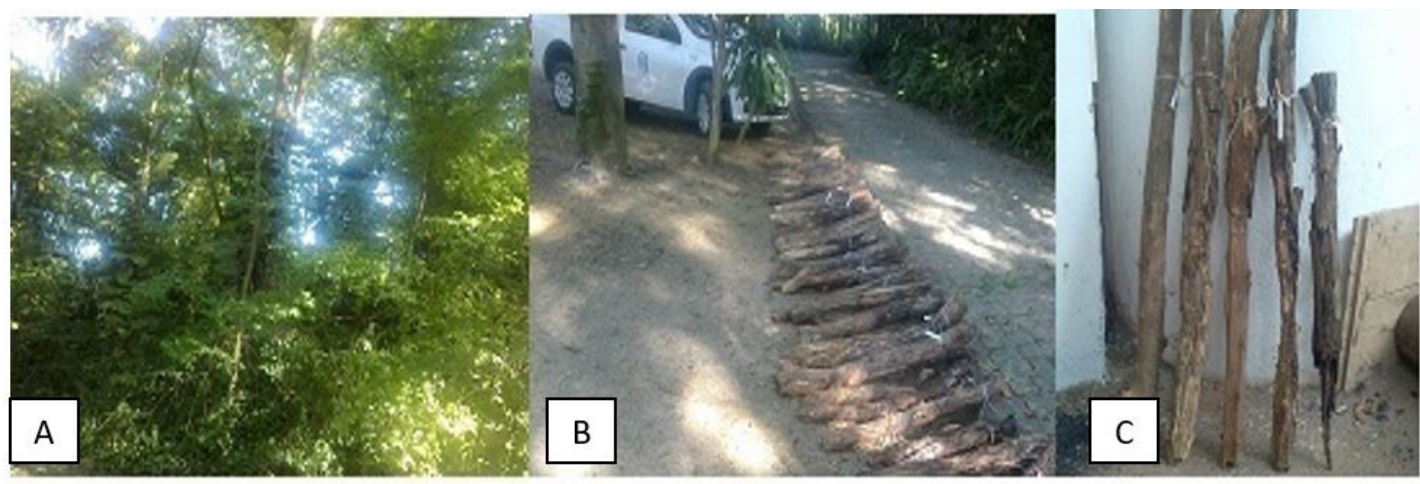

Figure 1. (A) Forest fragment where the experiment was conducted; (B) sabiá logs evaluated; (C) Logs classified (from left to right) as sound, surface attack, moderate attack, intensive attack (heavy) and failure (broken), respectively. 
for Research, Technical Assistance and Rural Extension (INCAPER), located in the municipality of Viana, Espírito Santo, Brazil (20²3' 25” S and 40²9'46” W, at 34 meters of altitude). The region's climate is Aw according to the Köppen-Geiger climatic classification, and the average annual rainfall is $1,546 \mathrm{~mm}$.

In order to characterize the soil at the experimental site, three samples were collected at three equidistant points along the log fixation line. Physical granulometric analysis, textural classification and soil chemical attributes are shown in Tables 1 and 2, respectively.

Log evaluation was performed after 5 years and 5 months of exposure. Log circumference measurements were taken using a measuring tape, $10 \mathrm{~cm}$ above ground level (aerial part). Mechanical force was subsequently applied to verify the resistance of the wood logs to breaking, as indicated by the American Society for Testing and Materials - ASTM D-1758 (ASTM, 2005). The logs were removed from the soil (Figure 1B) and evaluated for their resistance status using ratings (Table 3 and Figure $1 \mathrm{C}$ ). The ratings were given through assessments conducted by five observers and the presence of subterranean termites and fungi responsible for white or brown rot in the logs was recorded.

After the field evaluation, the circumference was measured without the bark at a position corresponding to $10 \mathrm{~cm}$ above (aerial part) and below (underground) ground level. The areas in the two positions and relative area loss of the underground part in relation to the

Table 1. Physical granulometric analysis and textural classification of the soil at the experimental site.

\begin{tabular}{cccccc} 
Sample & $\begin{array}{c}\text { Coarse } \\
\text { Sand }\end{array}$ & $\begin{array}{c}\text { Fine } \\
\text { Sand }\end{array}$ & Silt & Clay & $\begin{array}{c}\text { Textural } \\
\text { Class }\end{array}$ \\
\cline { 2 - 4 }$\left(\mathbf{g ~ k g}^{-1}\right)$ & & \\
1 & 436 & 116 & 105 & 343 & $\begin{array}{c}\text { Sandy } \\
\text { Clay Loam }\end{array}$ \\
2 & 308 & 86 & 164 & 442 & Clay \\
3 & 285 & 94 & 139 & 482 & Clay \\
\hline
\end{tabular}

aerial part were calculated. The logs were sectioned at $10 \mathrm{~cm}$ below ground level (underground part), and the remaining proportions of sapwood and heartwood were calculated.

The logs were grouped into two diameter classes; 5.0 to 7.9 and 8.0 to $11.0 \mathrm{~cm}$, and the values were statistically analyzed using a completely randomized design and a comparison between averages at 5\% significance by the F test, as two treatments were used.

\section{RESULTS AND DISCUSSION}

The average diameter of the logs with bark for the highest evaluated class was $2.40 \mathrm{~cm}$, higher than those in the lowest class; and the difference was $2.20 \mathrm{~cm}$ without the bark, where the lower class had nine more posts than the higher class (Table 4).

The wood logs were attacked by the xylophagous agents in the soil, which was evidenced by a decrease in the diameter of logs without bark, where the values obtained for the aerial and underground parts showed a reduction of $1.50 \mathrm{~cm}$ for the smaller diameter class, and $2.00 \mathrm{~cm}$ for the thicker posts. This difference is related to the sapwood proportion in the logs and the greater amount of juvenile wood, which has diminished natural resistance to xylophagous agent.

No statistical difference was found between reductions in diameter of the wood pieces between the evaluated classes, which had similar resistance to the xylophagous from the experimental site.

Wider logs had $2.38 \mathrm{~cm}$ more heartwood, corresponding to an increase of $14.42 \%$ of heartwood in these pieces (Table 5). The heartwood:sapwood ratio was higher in the larger diameter class, conferring greater durability. This probably occurred due to the greater quantity of extractives in these pieces, since the class and quantity of extractives in the wood are responsible for its greater resistance to xylophagous agent (Findlay, 1985). Moreover, the proportion of

Table 2. Chemical attributes of the soil at the experimental site.

\begin{tabular}{|c|c|c|c|c|c|c|c|c|c|c|c|c|c|}
\hline \multirow{2}{*}{ Sample } & \multirow{2}{*}{ pH } & $\mathbf{P}$ & $\mathbf{K}$ & $\mathrm{Ca}$ & $\mathrm{Mg}$ & Al & $\mathrm{H}+\mathrm{Al}$ & SB & $t$ & $\mathbf{T}$ & \multirow{2}{*}{$\begin{array}{c}\mathrm{V} \\
(\%)\end{array}$} & \multirow{2}{*}{$\begin{array}{c}\text { m } \\
(\%)\end{array}$} & \multirow{2}{*}{$\frac{\mathrm{OM}}{\left(\mathrm{dag} \mathrm{kg}^{-1}\right)}$} \\
\hline & & \multicolumn{2}{|c|}{$\left(\mathrm{mg} \mathrm{dm}^{-3}\right)$} & \multicolumn{7}{|c|}{$\left(\mathrm{cmolc} \mathrm{dm}^{-3}\right)$} & & & \\
\hline 1 & 4.9 & 4.2 & 52 & 1.24 & 0.69 & 0.85 & 5.0 & 2.07 & 2.92 & 7.07 & 29.3 & 29.1 & 1.22 \\
\hline 2 & 4.8 & 2.2 & 39 & 1.17 & 0.59 & 0.95 & 5.0 & 1.86 & 2.81 & 6.86 & 27.1 & 33.8 & 1.13 \\
\hline 3 & 4.7 & 1.4 & 50 & 0.84 & 0.61 & 1.10 & 4.5 & 1.58 & 2.68 & 6.08 & 26.0 & 41.0 & 0.63 \\
\hline
\end{tabular}

SB: Exchangeable base sum; t: Effective cation exchange capacity; T: Cation exchange capacity at pH 7.0; V: Base Saturation Index; $\mathrm{m}$ : Aluminum saturation index; OM: Organic matter. 
juvenile and adult wood influences natural resistance, since juvenile wood cells have thinner walls, lower density (Vidaurre et al., 2011), and consequently fewer extractives present in them.

The average percentage of breakage was $19.60 \%$, in which the largest diameter class had 3.40\% less broken posts than those of the lower class. The breakages occurred in the outcrop region, and were caused both by the action of termites (Nasutitermes sp. or Heterotermes sp.) and of fungi responsible for white (presence of clear areas delineated by dark lines with a fibrous aspect of the attacked part) and brown rot

Table 3. Evaluation of the field trial based on the condition of the logs.

\begin{tabular}{cc|}
\hline Condition of the Logs & Damage (Rating) \\
\hline Sound & 10 \\
\hline Surface Attack & 9 \\
\hline Moderate Attack & 7 \\
\hline Intensive Attack (Heavy) & 4 \\
\hline Failure (Broken) & 0 \\
\hline
\end{tabular}

Source: Adapted from Becker (1972) and Cavalcante et al. (1975). (darkening, longitudinal and transverse cracks with a non-fibrous aspect of the attacked part) (Table 6). The most intensive attacks occurred on the smaller diameter posts, except for brown rot where larger diameter pieces suffered more attacks. The action of each xylophagous agent was measured in relation to the total number of evaluated logs.

The observed values for xylophagous attack between the diameter classes of tested sabiá logs were not sufficient to cause a difference between the damage ratings attributed to the wood, being classified from intensive to moderate.

The total number of unbroken logs was $81.82 \%$ and $79.24 \%$, respectively, for the larger and smaller diameter classes (Table 7), which suffered superficial to intensive attacks. Therefore, after 5 years and 5 months of exposure to experimental conditions, approximately $20 \%$ of the wood pieces would have to be replaced to maintain the fence. This shows that sabiá wood has enough natural resistance to be used under edaphoclimatic

Table 4. Diameters of aerial and underground parts of sabiá logs (Mimosa caesalpiniifolia) and reduction of the bark-less diameter between the parts for the diameter classes.

\begin{tabular}{|c|c|c|c|c|c|}
\hline \multirow[b]{2}{*}{$\begin{array}{c}\text { Diameter } \\
\text { Classes }(\mathbf{c m})\end{array}$} & \multirow[b]{2}{*}{$\begin{array}{l}\text { Number } \\
\text { of Logs }\end{array}$} & \multicolumn{2}{|c|}{ Aerial Part } & \multicolumn{2}{|c|}{ Underground Part } \\
\hline & & $\begin{array}{c}\text { Diameter with } \\
\text { Bark } \\
(\mathrm{cm})\end{array}$ & $\begin{array}{c}\text { Diameter } \\
\text { without Bark } \\
(\mathrm{cm})\end{array}$ & $\begin{array}{l}\text { Diameter } \\
\text { with Bark } \\
(\mathrm{cm})\end{array}$ & $\begin{array}{c}\text { Reduction } \\
\text { of Diameter } \\
(\%)\end{array}$ \\
\hline $5.0-7.9$ & 53 & 6.90 & 6.20 & 4.70 & $24.19 a$ \\
\hline $8.0-11.0$ & 44 & 9.30 & 8.40 & 6.40 & $23.81 \mathrm{a}$ \\
\hline Average & - & 8.10 & 7.30 & 5.55 & 24.00 \\
\hline
\end{tabular}

Means followed by the same lowercase letter in the column did not differ statistically by the F test ( $\mathrm{p}>0.05)$.

Table 5. Heartwood and sapwood proportions, and heartwood:sapwood ratio of sabiá logs (Mimosa caesalpiniifolia) for both diameter classes evaluated.

\begin{tabular}{cccccc}
$\begin{array}{c}\text { Diameter Class } \\
(\mathbf{c m})\end{array}$ & $\begin{array}{c}\text { Heartwood } \\
\text { Diameter } \\
(\mathbf{c m})\end{array}$ & $\begin{array}{c}\text { Sapwood } \\
\text { Thickness } \\
(\mathbf{c m})\end{array}$ & $\begin{array}{c}\text { Heartwood } \\
(\mathbf{\%})\end{array}$ & $\begin{array}{c}\text { Sapwood } \\
(\%)\end{array}$ & $\begin{array}{c}\text { Heartwood: } \\
\text { Sapwood Ratio }\end{array}$ \\
\hline $5.0-7.9$ & 4.30 & 0.94 & 49.84 & 50.16 & $1.16 \mathrm{~b}$ \\
\hline $8.0-11.0$ & 6.68 & 0.84 & 64.26 & 35.74 & $2.07 \mathrm{a}$ \\
\hline Average & 5.38 & 0.89 & 56.38 & 43.62 & 1.57 \\
\hline
\end{tabular}

Means followed by the same lowercase letter in the column did not differ statistically by the F test ( $\mathrm{p}>0.05)$.

Table 6. Percentage of failure (broken) logs due to termites, white and brown rot, and damage ratings of sabiá wood (Mimosa caesalpiniifolia) per diameter class.

\begin{tabular}{|cccccc|}
$\begin{array}{c}\text { Diameter Class } \\
(\mathbf{c m})\end{array}$ & $\begin{array}{c}\text { Breakage } \\
(\mathbf{\%})\end{array}$ & $\begin{array}{c}\text { Termite } \\
(\mathbf{\%})\end{array}$ & $\begin{array}{c}\text { White rot } \\
\mathbf{( \% )}\end{array}$ & $\begin{array}{c}\text { Brown rot } \\
(\mathbf{\%})\end{array}$ & $\begin{array}{c}\text { Damage } \\
\text { (Rating) }\end{array}$ \\
\hline $5.0-7.9$ & 20.80 & 71.70 & 84.91 & 13.21 & $4.03 \mathrm{a}$ \\
$8.0-11.0$ & 17.40 & 54.35 & 69.57 & 26.09 & $5.30 \mathrm{a}$ \\
\hline Average & 19.60 & 64.90 & 79.40 & 19.60 & 4.60 \\
\hline
\end{tabular}

Means followed by the same lowercase letter in the column do not differ statistically by the F test ( $\mathrm{p}>0.05)$. 
Table 7. Assessment of the condition of Sabiá logs (Mimosa caesalpiniifolia) for each diameter class.

\begin{tabular}{|c|c|c|c|c|c|}
\hline \multirow{3}{*}{ Damage (Rating) } & \multirow{3}{*}{ Condition of the Logs } & \multicolumn{4}{|c|}{ Diameter Class (cm) } \\
\hline & & \multicolumn{2}{|c|}{$5.0-7.9$} & \multicolumn{2}{|c|}{$8.0-11.0$} \\
\hline & & Number & $(\%)$ & Number & $(\%)$ \\
\hline $10.0-9.2$ & Sound & 0 & 0 & 2 & 5 \\
\hline $9.0-7.4$ & Surface Attack & 6 & 11 & 16 & 36 \\
\hline $7.0-4.6$ & Moderate Attack & 22 & 42 & 9 & 20 \\
\hline $4.0-0.8$ & Heavy (Intensive Attack) & 14 & 26 & 9 & 20 \\
\hline 0.0 & Failure (Broken) & 11 & 21 & 8 & 18 \\
\hline Total & & 53 & 100 & 44 & 100 \\
\hline
\end{tabular}

conditions more favorable for the development of xylophagous organisms.

For the smaller diameter class, 28 logs (52.83\%) received average ratings above 4 (moderate to superficial attack), and 27 logs (61.36\%) received average ratings above 4 for the largest diameter class. For this diameter class, $18 \operatorname{logs}(41 \%)$ were only superficially attacked or were not attacked at all. These results corroborate those obtained by Lunz \& Carvalho (2002), Melo \& Paes (2006), Paes et al. (2007) and Alencar et al. (2011) who proved that Sabiá wood has good natural resistance to rotting fungi and xylophagous insects.

Taking into account that no vegetation was cleared around the logs, and that they were placed at the edge of a native forest fragment in soil with physical characteristics (Table 1), chemical attributes and a good level of organic matter (Table 2) conducive to xylophagous development, the natural durability of the logs can be considered good. Additionally, they could also be improved with care and maintenance of the fence. According to Paes et al. (2004), understanding the natural resistance of the species is of paramount importance to be able to recommend more appropriate uses for the wood, avoiding unnecessary expense with premature replacement of deteriorated parts.

\section{CONCLUSIONS}

An attack on the Sabiá wood by the xylophagous agents existing at the site was evidenced by the decrease in the diameter of the underground portion of the logs buried in the soil.

The percentage of failure (broken) logs was smaller in the larger diameter class due to the greater amount of heartwood.

Breakage was caused by subterranean termite action (Nasutitermes sp. or Heterotermes sp.) and or by fungi responsible for white and brown rot.
The logs received superficial to intensive attacks from the xylophagous organisms, but only $20 \%$ of the logs needed to be replaced for fence maintenance after 5 years and 5 months.

Due to the good performance of the Sabia logs against deterioration caused by fungi and termites, and especially due to the non-recommendation of treating wood with chemicals when used in organic agriculture, this wood meets the requirements for this purpose.

\section{ACKNOWLEDGEMENTS}

The agricultural technicians Afonso Carlos Valentim and Antonio Müller Neto participated in the deployment and data collection of the experiment, respectively and the agricultural technician Luiz Alberto Margoto, head of the Center for Improvement of Rural Leadership (CALIR), Capixaba Institute of Research, Technical Assistance and Rural Extension (INCAPER), made the area and care required for the development of the experiment available.

\section{SUBMISSION STATUS}

Received: 28 dec., 2015

Accepted: 21 may, 2017

\section{CORRESPONDENCE TO}

\section{Juarez Benigno Paes}

Departamento de Ciências Florestais e da Madeira, Universidade Federal do Espírito Santo - UFES, Av. Governador Lindemberg, 316, Centro, CEP 29500-000, Jerônimo Monteiro, ES, Brazil

e-mail: jbp2@uol.com.br 


\section{FINANCIAL SUPPORT}

No funding.

\section{REFERENCES}

Alencar FHH, Paes JB, Bakke AO, Silva GS. Resistência natural da madeira de sabiá (Mimosa caesalpiniifolia Benth.) a cupins subterrâneos. Caatinga 2011; 24(1): 57-64.

American Society for Testing and Materials - ASTM. ASTM D-1758: standard test method of evaluating wood preservatives by field tests with stakes. West Conshohocken: ASTM; 2005. $7 \mathrm{p}$

Becker G. Suggested standard method for field tests with wooden stakes. Pest Articles \& News Summaries 1972; 18(1): 137-142.

Carvalho FC, Garcia R, Araújo JÁ Fo, Couto L, Neves JCL, Rogério MCP. Manejo in situ do sabiá (Mimosa caesalpiniifolia Benth.) para a produção simultânea de madeira e forragem, em um sistema silvo pastoril. Agrossilvicultura 2004; 1(2): 121-129.

Carvalho PER. Sabiá: mimosa caesalpiniifolia. Colombo: Embrapa Floresta; 2007. 10 p. (Circular Técnica; no. 135).

Cavalcante MS, Lelis AT, Corsini CA, Kronka FJN, Coelho LCC, Montagna RG et al. Resultado das inspeções a cinco campos de apodrecimento após seis anos de implantação. Preservação de Madeiras 1975; 6-7(1): 7-20.

Findlay WPK. The nature and durability of wood. In: Findlay WPK, editores. Preservation of timber in the tropics.
Dordrecht: Martinus Nijhoff/ Dr. W. Junk Publishers; 1985. p. 1-13.

Gonçalves CA, Fernandes MM, Andrade AM. Celulose e carvão vegetal de Mimosa caesalpiniaefolia Benthan (sabiá). Floresta e Ambiente 1999; 6(1): 51-58.

Lunz AM, Carvalho AG. Degradação da madeira de seis essências arbóreas dispostas perpendicularmente ao solo causada por Scolytidae (Coleoptera). Neotropical Entomology 2002;31(3):351-357. http://dx.doi.org/10.1590/ S1519-566X2002000300002.

Melo RR, Paes JB. Resistência natural de quatro madeiras do semi-árido brasileiro a fungos xilófagos em condições de laboratório. Revista Caatinga 2006; 19(2): 169-175.

Paes JB, Melo RR, Lima CR, Oliveira E. Resistência natural de sete madeiras ao cupim subterrâneo (Nasutitermes corniger Motsch.) em ensaio de preferência alimentar. Agrária 2007; 2(1): 57-62.

Paes JB, Morais VM, Lima CR. Resistência natural de nove madeiras do semi-árido brasileiro a fungos xilófagos em condições de laboratório. Revista Árvore 2004; 28(2): 275 282. http://dx.doi.org/10.1590/S0100-67622004000200014.

Ribaski J, Lima PCF, Oliveira VR, Drumond MA. Sabiá (Mimosa caesalpiniaefolia) árvore de múltiplo uso no Brasil. Colombo: Embrapa Florestas; 2003. 4 p. (Comunicado Técnico; no. 104).

Vidaurre G, Lombardi LR, Oliveira JTS, Arantes MDC. Lenho juvenil e adulto e as propriedades da madeira. Floresta e Ambiente 2011; 18(4): 469-480. http://dx.doi. org/10.4322/floram.2011.066. 